\title{
Papillary and Follicular Thyroid Carcinoma : Impact of Treatment in 44 patients at the Cipto Mangunkusumo Hospital
}

\author{
Cholid Badri, Olivia Kuswanto, Soehartati Gondhowiardjo, Bangun Astarto, Kahar Kusumawijaya
}

\begin{abstract}
Abstrak
Telah dilakukan pengamatan terhadap hasil terapi I-131 pada 44 penderita karsinoma tiroid berdiferensiasi baik. Jenis histopatologiknya ialah karsinoma papiler pada 30 penderita, dan karsinoma folikular pada 14 penderita. Pada $11 \%$ penderita dijumpai metastasis ke kelenjar getah bening regional, dan pada $11 \%$ penderita sudah terdapat metastasis jauh. Pada 24 penderita karsinoma papiler tanpa metastasis, dan 10 penderita karsinoma folikular tanpa metastasis, diberikan dosis 80 mCi. Penderita dengan metastasis (6 penderita karsinoma papiler, dan 4 penderita karsinoma folikular) diberikan dosis $100 \mathrm{mCi}$. Dengan dosis permulaan $80 \mathrm{mCi}$, keberhasilan ablasi tercapai pada $58 \%$ penderita karsinoma papiler, sedangkan setelah siklus kedua, ablasi mencapai $79 \%$. Untuk kasus metastasis, perbaikan dijumpai pada 33\% setelah terapi permulaan $100 \mathrm{mCi}$, dan meningkat menjadi $67 \%$ setelah siklus kedua. Pada penderita karsinoma folikular, dengan dosis $80 \mathrm{mCi}$, angka keberhasilan ablasi mencapai 70\%, dan meningkat menjadi $80 \%$ setelah siklus kedua. Perbaikan pada kasus metastasis baru dijumpai setelah terapi siklus kedua (50\%). Ternyata, keberhasilan ablasi dengan dosis 80 mCi lebih tinggi pada karsinoma folikular dari pada karsinoma papiler, sedangkan untuk terapi lesi metastatik pada kedua jenis histopatologik, agaknya diperlukan dosis yang lebih besar dari $100 \mathrm{mCi}$.
\end{abstract}

\begin{abstract}
Therapeutic responses of 44 patients with well differentiated thyroid carcinoma who had received I-131 therapy were evaluated. Thirty patients had papillary carcinoma and fourteen with follicular carcinoma. Of these, $11 \%$ patients had metastases to regional nodes and $11 \%$ had distant metastases. 1 - 131 therapy with the dose of $80 \mathrm{mCi}$ was given to 24 patients with papillary carcinoma and 10 patients with follicular carcinoma who had no distant metastases. Patients with distant metastases consisting of 6 patients with papillary carcinoma and 4 patients with follicular carcinoma were treated with $100 \mathrm{mCi}$ I-131. Of the patients with papillary carcinoma successful ablation was obtained in $58 \%$ patients with a $80 \mathrm{mCi}$ initial dose and increased to $79 \%$ patients after the second dose. Metastatic control was obtained in $33 \%$ patients with $100 \mathrm{mCi}$ and increased to $67 \%$ patients after the second dose. Of the patients with follicular carcinoma, successful ablation was obtained in $70 \%$ patients and increased to $80 \%$ patients after the second dose. Metastatic control was obtained in $50 \%$ patients after the second dose. It is assumed that efficacy of ablation with $80 \mathrm{mCi}$ as initial dose is higher in patients with follicular carcinoma than the papillary type, while the metastatic lesions in both histologic types should be treated with more additional doses of $100 \mathrm{mCi}$.
\end{abstract}

Keywords : Thyroid carcinoma, Papillary type, Follicular type, Treatment of thyroid carcinoma

\section{INTRODUCTION}

Radioactive iodine - 131 (I-131) has been used in the treatment of thyroid carcinoma since the $1940 \mathrm{~s}^{3,6}$

Although majority of the thyroid carcinoma can be removed surgically, there is often uncertainty as to the completeness of the resection and the presence of local or distant histologic metastases, despite the absence of clinically detectable abnormalities. In fact, remnants of non malignant thyroid tissue are nearly always present after surgery performed for thyroid carcinoma, and their ablation with I-131 is associated with decreased recurrence rates and probably increased survival. The rationale for the use of I-131 is that residual thyroid tissue will concentrate enough of the radioactive isotope to cause self destruction. $3,4,7,10,12$

There are various opinions on the amount of dose that should be administered. A dose of I-131 in the range of $50-150 \mathrm{mCi}$ are customarily used to ablate thyroid remnants. According to Ramacciotti et al, ${ }^{10}$ 
complete ablation of thyroid tissue occurred after a single $30 \mathrm{mCi}$ dose in $40 \%$ of the patients. A low dose therapy with $30 \mathrm{mCi}$ was advocated by $\mathrm{Mc}$ Cowen et al. $^{8}$ Krishnamurthy and Blahd ${ }^{5}$ administered a 75-150 $\mathrm{mCi}$ dose of I-131. The recurrence rate for patients with metastases was $56 \%$ and those without metastases was $25 \%$ within 25 years. Blahd et al ${ }^{1}$ gave a $100 \mathrm{mCi}$ dose of I-131. The results were $55 \%$ of patients lived more than 3 years, and $27 \%$ lived more than 5 years. With a 50-200 mCi dose of I-131, Maheshwari et al. ${ }^{6}$ found at a 20 -year follow-up, $78 \%$ of papillary carcinoma patients and $68 \%$ of follicular carcinoma patients had survived.

Patients with metastases have a higher incidence of recurrence than those who have localized thyroid disease. ${ }^{6,11}$ When metastases are to be treated with I-131, thyroid tissue remaining after thyroidectomy is first treated with I-131. Pochin ${ }^{9}$ found that $50 \%$ of the patients with differentiated thyroid carcinoma treated with I-131 had excellent responses and that an additional $25 \%$ had good palliation. Patients with mediastinal metastases were most likely to respond to I-131 therapy while most patients with bone and brain metastases died of their disease. ${ }^{2}$

The aim of this study is to determine the efficacy of $80 \mathrm{mCi}$ I- 131 in ablating the thyroid remnants, and of $100 \mathrm{mCi}$ in controlling metastatic foci as well.

\section{PATIENTS AND METHODS}

Between January 1990 and December 1991, 57 patients with well differentiated thyroid carcinoma were referred to the Radiotherapy Unit, Cipto Mangunkusumo Hospital for I-131 therapy.

\section{Selection of the patients}

Among 57 patients, 13 patients have been excluded from this study. The reasons were : (1) 9 patients were lost to follow-up, or with follow-up periods less than 3 months; (b) 4 patients received the old $50 \mathrm{mCi}$ dose of I-131 regimen. All of the 44 patients who comprised the basis for this study had some form of thyroid surgery prior to I-131 therapy. The patients have been followed for more than 3 months.

\section{Therapeutic Procedure}

An outline of the procedure followed is given in figure 1. As indicated, an initial effort was made to detect thyroid remnants from previous surgery by performing the thyroid I-131 scan. A scintigram was obtained 4 weeks after the surgical procedure with a $1 \mathrm{mCi}$ dose of I-131. All patients received thyroid hormone replacement until 2 weeks before the scan. If post surgical thyroid remnants were detected by thyroid scan, the patients were referred to the Radiotherapy Unit, Cipto Mangunkusumo Hospital. The patients were placed on a low-iodine diet. If only thyroid bed remnants were present, the ablation dose of $80 \mathrm{mCi}$ was given. If nodal or distant metastases were found, the dose of $100 \mathrm{mCi}$ was administered. Some laboratory tests were required: T3, T4, TSH levels, serum thyroglobulin levels, haemoglobin, WBC, and thrombocyte counts. Hospitalization in an isolated room at the Radiotherapy Unit was needed during I-131 administration. The patients were instructed to drink large quantities of water and empty the bladder frequently to reduce bladder and whole-body irradiation. Any side effects occurring during the procedure were observed. Waste products (urine and stools) of the patients were handled by the National Atomic Energy Agency (BATAN). The body uptake was measured by a survey-meter (GM-counter) detector 1 hour following administration of the $80 \mathrm{mCi}$ dose of I-131. The count was repeated 48-72 hours later. The patients were released from the hospital if the count was less than 0,37 $\mathrm{mR} /$ hour at a distance of 3 meters.

A postablation survey scan was performed a week after the administration of the $80 \mathrm{mCi}$ dose of I- 131 . This whole-body scan is important for base-line data and detecting distant metastases foci as well. Clinical examination was performed regularly after one week, one month, 3 months, 6 months, and once a year following the ablation procedure. The whole-body scan was repeated 3 months after the initial treatment with the $5 \mathrm{mCi}$ dose of I-131. If the scan revelaed no evidence of metastases nor thyroid remnants, or showed only minimal thyroid remnants, suppressive doses of thyroid hormone should be continued. The same procedure was repeated at 6 months, one year, and subsequently every 2 years. If the scan still revealed thyroid remnants without nodal nor distant metastases, an additional $80 \mathrm{mCi}$ dose of I- 131 should be given. If functioning metastases were still evident with or without thyroid remnants, an additional 100 $\mathrm{mCi}$ dose of I-131 should be administered. At least 6 months follow-up after the second I-131 administration was noted to evaluate the efficacy of I-131 therapy.

\section{Characteristics of the patients}

The age and sex distribution according to histologic type of the 44 patients who were studied is shown in table 1 and table 2 . 


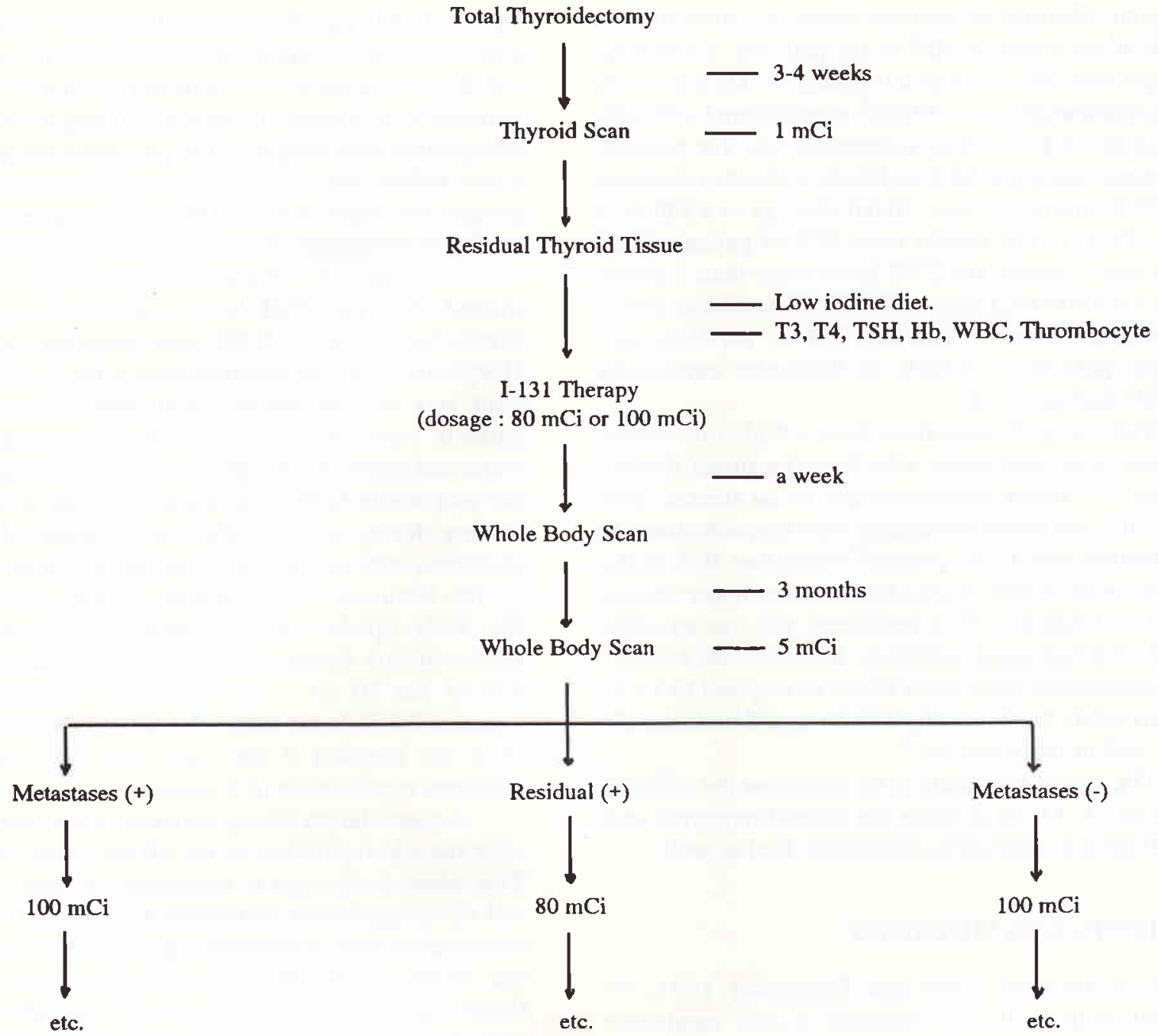

Figure 1. Therapeutic I-131 procedure Radiotherapy Unit, Cipto Mangunkusumo Hospital

Table 1. Age distribution of patients with differentiated thyroid carcinoma

\begin{tabular}{rccr}
\hline Age (years) & Papillary & Follicular & Total \\
\hline$<20$ & 2 & - & 2 \\
$21-30$ & 3 & 2 & 5 \\
$31-40$ & 7 & 2 & 9 \\
$41-50$ & 7 & 2 & 9 \\
$52-60$ & 8 & 3 & 11 \\
$>60$ & 3 & 5 & 8 \\
\hline Total & 30 & 14 & 44 \\
\hline
\end{tabular}

Table 2. Sec distribution of patients with differentiated thyroid carcinoma

\begin{tabular}{lccr}
\hline & Papillary & Follicular & Total \\
\hline Male & 6 & 2 & 8 \\
Female & 24 & 12 & 36 \\
\hline Total & 30 & 14 & 44 \\
\hline
\end{tabular}

The histopathological type of the tumors observed in this study were predominantly papillary carcinoma ( 30 patients, $68 \%$ ). The incidence of papillary 
carcinoma was higher in the age group of 40-60 years (15 patients, $50 \%$ ). Of the 14 patients with follicular carcinoma, most were more than 50 years old ( 8 patients, $57 \%$ ). Of the patients studied, 36 patients $(82 \%)$ were female and 8 patients $(18 \%)$ were male.

\section{Extension of disease}

Concerning the extension of tumors, the patients were divided into three groups; i.e. locally, regional metastases, and distant metastases. Patients who developed metastases were classified according their age groups (table 3 and table 4).

Table 3. Extension of tumors

\begin{tabular}{lccr}
\hline & Papillary & Follicular & Total \\
\hline Locally & 24 & 10 & 34 \\
Regional metast & 4 & 1 & 5 \\
Distant metast & 2 & 3 & 5 \\
\hline Total & 30 & 14 & 44 \\
\hline
\end{tabular}

Table 4. Age distribution of patients with regional and distant metastases

\begin{tabular}{cccc}
\hline Age (years) & Regional & Distant & Total \\
\hline$<20$ & - & - & - \\
$21-30$ & - & - & - \\
$31-40$ & 1 & - & - \\
$41-50$ & 2 & 1 & 3 \\
$51-60$ & 2 & 3 & 5 \\
$>60$ & - & 1 & 1 \\
\hline Total & 5 & 5 & 10 \\
\hline
\end{tabular}

Most of the patients with differentiated tumors showed locally diseases : 24 patients $(80 \%)$ in the papillary group, and 10 patients $(71 \%)$ in the follicular group. Regional metastases were found predominantly in papillary tumors (4 patients, $40 \%$ ), while distant metastases in follicular tumors ( 2 patients, $30 \%$ ). No metastatic foci developed in the younger aged (below 30 years). Most of the regional metastases were found in the age group of 41-60 years, while distant metastases in the age group of 51-60 years.

\section{Dose specification}

I-131 doses were divided into 2 groups the : $80 \mathrm{mCi}$ dose was given to patients with thyroid bed remnants, and the $100 \mathrm{mCi}$ dose was given to patients with metastatic foci with or without thyroid remnants. The evaluation of therapy was made by means of the wholebody scan. The whole-body scan was performed 3 months following the initial (1st cycle) and additional (2nd cycle) I- 131 therapy. The additional $80 \mathrm{mCi}$ or $100 \mathrm{mCi}$ dose of I-131 was administered 3-4 months following the initial therapy. The results of patients with papillary thyroid carcinoma are reported separately from follicular carcinoma. The improvement is determined by a negative scan or reduced remnant size and uptake.

Table 5. Results of I-131 therapy in papillary thyroid carcinoma $\mathrm{n}=\mathbf{3 0}$

\begin{tabular}{rrrcc}
\hline & \multicolumn{4}{c}{ Whole-body scan } \\
\hline Cycle & mCj & n & Remnant & Remnants + Metastases \\
\hline I & 80 & 24 & $10^{*}$ & - \\
& 100 & 6 & - & 4 \\
\hline II & 80 & 7 & 2 & - \\
& 100 & 4 & - & 2 \\
\hline
\end{tabular}

Note : ${ }^{*}: 3$ patients with thyroid remnants after the 1 st cycle were lost to follow-up.

Table 6. Results of I-131 therapy in follicular thyroid carcinoma

$$
\mathrm{n}=14
$$

\begin{tabular}{crccc}
\hline & \multicolumn{4}{c}{ Whole-body scan } \\
\hline Cycle & $\mathrm{mCi}$ & $\mathrm{n}$ & Remnant & Remnants + Metastases \\
\hline I & 80 & 10 & 2 & $1^{\star}$ \\
& 100 & 4 & - & 4 \\
\hline II & 80 & 2 & 1 & - \\
& 100 & 4 & - & 2 \\
\hline
\end{tabular}

Note : * : One patient with thyroid remnants and metastases was lost to follow-up

\section{RESULTS}

Papillary Thyroid Carcinoma :

Of the patients with papillary carcinoma who received a $80 \mathrm{mCi}$ dose of I-131 in the 1st cycle, improvement 
was obtained in 14 patients ( $58 \%$ ). After the 2 nd cycle therapy with the same dose, 19 patients $(79 \%)$ showed improvement.

Of the 6 patients with metastatic foci who received a $100 \mathrm{mCi}$ dose of $\mathrm{I}-131$ in the 1 st cycle, improvement was gained in 2 patients (33\%). After the 2nd cycle with the same dose, 4 patients $(67 \%)$ showed improvement. (Table 5).

\section{Follicular Thyroid Carcinoma}

Of the 10 patients who received a $80 \mathrm{mCi}$ dose of I-131 in the 1st cycle, improvement was obtained in 7 patients (70\%). After the 2nd cycle therapy with the same dose, improvement was gained in 8 patients $(80 \%)$.

Of the 4 patients with metastatic foci who received a $100 \mathrm{mCi}$ dose of I-131, improvement was observed in 2 patients $(50 \%)$ after the 2 nd cycle. (Table 6)

\section{Complications of I-131 therapy}

The short-term complications were observed during the hospitalization. The majority of symptoms were divided into 3 groups : (6) local effects, consisting of pain and edema at the neck; (3) upper respiratory symptoms, consisting of coughing, dysphonia, dyspnea, chest discomfort; (4) upper GI symptoms, consisting of nausea, vomiting, stomachache (table 7).

Table 7. Short-term complications of I-131 therapy

\begin{tabular}{lc}
\hline Symptoms & Total \\
\hline Local Effects & 4 \\
Upper Respiratory Tract & 3 \\
Upper Gastrointestinal Tract & 4 \\
\hline Total & 11 \\
\hline
\end{tabular}

Mild complications occured in 11 patients (25\%) during the hospitalization. Symptomatic drugs were given and the symptoms decreased within a week. No serious complication was noted. Long- term complications were not available because most of them were lost to follow-up.

\section{DISCUSSION}

The management of papillary and follicular thyroid carcinoma remains controversial in many of its aspects. At present, it is generally accepted that surgery is the primary form of therapy for thyroid carcinoma. Three objectives are achieved with surgical thyroidectomy, i.e. removal of most of the primary and possibly secondary sites of tumor; augmentation of I-131 concentration by metastatic foci; and reduction of the total I- 131 dose required to achieve total ablation. ${ }^{5,12}$ Residual thyroid tissue is localized by scintiscan of the thyroid.

The administration of thyroid hormone in doses sufficient to suppress the release of TSH by the pituitary gland is an essential component in the management of papillary and follicular thyroid carcinoma, recognizing the ability of TSH to stimulate both growth and function of normal and tumorous thyroid tissue. $^{12}$

Depending on the extent of the disease, a certain dose of I-131 is given to ablate residual tissue and/or metastatic foci. The uptake of I-131 by thyroid remnants are augmented by reducing iodine intake and withdrawing the thyroid hormone replacement. ${ }^{2}$ Follow-up is made by means of whole body scan.

In this study, 44 patients were referred for I-131 therapy. Surgical resection was carried out in all patients. Ten $(23 \%)$ patients had metastases at the time of initial I-131 therapy (table 3). Patients with residual thyroid tissue received a $80 \mathrm{mCi}$, while patients with metastatic foci received a $100 \mathrm{mCi}$ dose of I-131. After the initial $80 \mathrm{mCi}$ dose of I-131, improvement were obtained in $58 \%$ of the patients in the papillary group, and $70 \%$ of the patients in the follicular group. Following the second treatment, the improvement was higher (79\%-80\%). However, patients with metastases responded poorly to therapy. Improvement were achieved only in $33 \%$ of the papillary group on initial therapy. After the second cycle, the improvement increased to $50 \%-67 \%$. No major complications attributable to the therapeutic doses of I-131 employed in this series were noted. Some patients ( 3 patients in the papillary group, 1 patient in the follicular group) were lost to follow-up after the initial I-131 treatment. The duration of the follow-up was not sufficient to permit any conclusion regarding survival or recurrence of disease.

\section{CONCLUSIONS}

Therapeutic responses of patients with well differentiated thyroid carcinoma treated by I-131 depend on the histologic type and the dose of I- 131.

It seems that a higher dose of $\mathrm{I}-131$ is needed to achieve a successful ablation or to control metastatic lesions. The dose should be given once or in several months interval. 


\section{REFERENCES}

1. Blahd WH, Nordyke RA, Bauer FK. Radioactive Iodine (I-131) in the Postoperative Treatment of Thyroid Cancer. Cancer $1960 ; 13: 745-54$.

2. Harbert JC. Radioiodine therapy of differentiated thyroid carcinoma. In : Nuclear medicine therapy. New York : Thieme 1987 : 47-65.

3. Hershman JM, Blahd WH, Gordon HE. Thyroid gland. In : Haskell CM, ed. Cancer treatment. Philadelphia : Saunders $1990: 409-13$.

4. James AG, Farrar WB, Cooperman M. Tumors of the thyroid and parathyroid. In : Pilch YH, ed. Surgical oncology. New York : McGraw-Hill 1984 : 418-20.

5. Krishnamurthy GT, Blahd WH. Radioiodine I-131 therapy in the management of thyroid cancer, a prospective study. Cancer 1977; $40: 195-202$.

6. Maheshwari YK, Stratton Hill C, Haynie TP, Hickey RC, Samaan NA. I-131 Therapy in differentiated thyroid carcinoma : M.D. Anderson Hospital experience. Cancer 1981; $47: 664-71$.
7. Mazzaferri EL, Young RL. Papillary Thyroid Carcinoma : a 10 year follow-up report of the impact of therapy in 576 patients. Am J Med 1981; 70 : 511-7.

8. McCowen KD, Adler RA, Ghaed N, et al : Low dose radioiodide thyroid ablation in post surgical patients with thyroid cancer. Am J Med $61:$ 52-58, 1976.

9. Pochin EE : Prospects from the treatment of thyroid carcinoma with radioiodine. Clin Radiol. 1967; 18 : 113.

10. Ramacciotti C, Pretorius HT, Line BR, Goldman JM, Robbins J. Ablation of nonmalignant thyroid remnants with low doses of radioactive iodine : concise communication. J Nucl Med 1982; 23 : 483-9.

11. Ruegemer JJ, Hay ID, Bergstralh EJ, Ryan JJ, Offord KP, Gorman CA. Distant metastases in differentiated thyroid carcinoma : a multivariate analysis of prognostic variables. J Clin Endocrinol Metabol. 1988; 67 : 501-7.

12. Simpson WJ, Panzarella T, Carruthers JS, Gospodarowicz MK, Sutchliffe SB. Papillary and follicular thyroid cancer : impact of treatment in 1578 patients. Int J Radiation Oncol Biol Phys 1988; 14 : 1063-75. 